\title{
Erratum: Voluntary Self-touch Increases Body Ownership
}

\author{
Frontiers Production Office* \\ Frontiers Production Office, Frontiers, Lausanne, Switzerland
}

Keywords: sense of body ownership, sense of agency, self-touch, rubber hand illusion, multisensory integration, volition, robotics and haptic technology

\section{An erratum on}

Voluntary self-touch increases body ownership by Hara, M., Pozeg, P., Rognini, G., Higuchi, T., Fukuhara, K., Yamamoto, A., et al. (2015). Front. Psychol. 6:1509. doi: 10.3389/fpsyg.2015.01509

Reason for Erratum:

Due to a typesetting error, elements of Figure 1, panel C were partially cropped. The publisher apologizes for this error and the correct version of Figure 1 appears below.

This error does not change the scientific conclusions of the article in any way.

Original article has been updated.

A

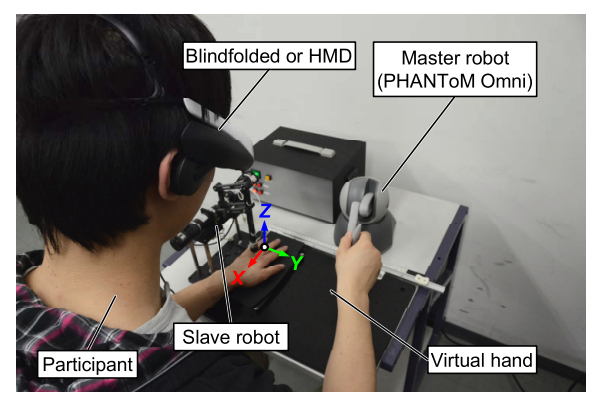

OPEN ACCESS

Approved by:

Psychology Editorial Office,

Frontiers, Switzerland

*Correspondence:

Frontiers Production Office production.office@frontiersin.org

Specialty section: This article was submitted to

Consciousness Research,

a section of the journal

Frontiers in Psychology

Received: 05 November 2015 Accepted: 05 November 2015 Published: 17 November 2015

Citation:

Frontiers Production Office (2015) Erratum: Voluntary Self-touch Increases Body Ownership. Front. Psychol. 6:1786. doi: 10.3389/fpsyg.2015.01786

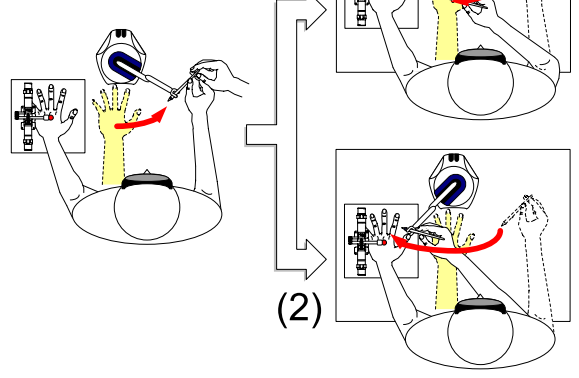

FIGURE 1 | Experimental setup and paradigm.
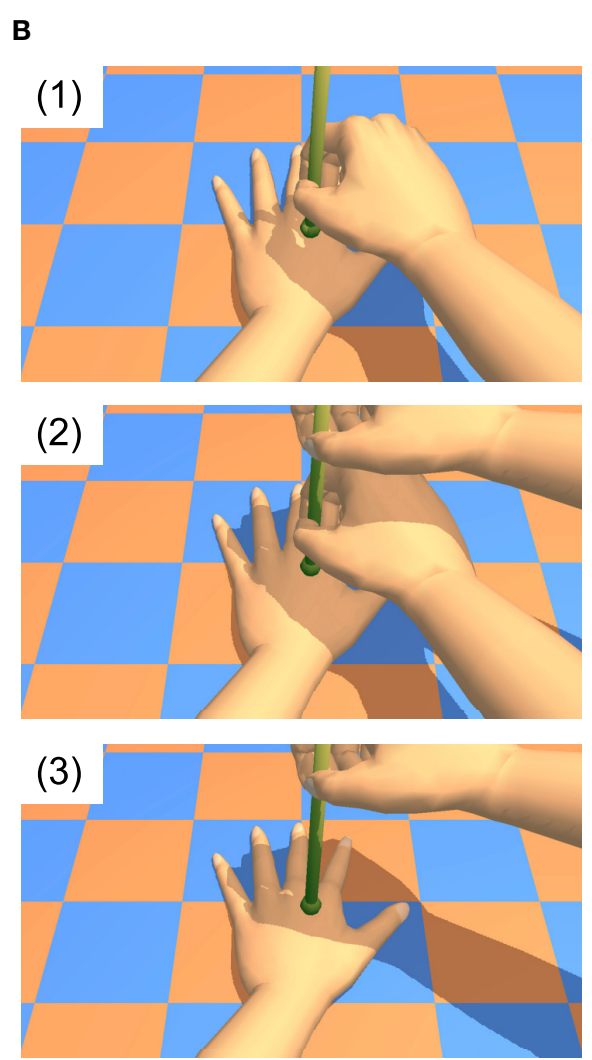

Copyright $\odot 2015$ Frontiers Production Office. This is an open-access article distributed under the terms of the Creative Commons Attribution License (CC BY). The use, distribution or reproduction in other forums is permitted, provided the original author(s) or licensor are credited and that the original publication in this journal is cited, in accordance with accepted academic practice. No use, distribution or reproduction is permitted which does not comply with these terms. 